\title{
Los Amerindios frente al Covid-19
}

Estado del arte y revista de prensa

\section{Paul Codjia et Raphaël Colliaux}

\section{(2) OpenEdition} Journals

Édition électronique

URL : https://journals.openedition.org/jsa/19799

DOI : 10.4000/jsa. 19799

ISSN : 1957-7842

Cet article est une traduction de :

Les Amérindiens face au Covid-19 - URL : https://journals.openedition.org/jsa/19674 [fr]

Autre(s) traduction(s) de cet article :

Amerindians in the face of Covid-19 - URL : https://journals.openedition.org/jsa/19797 [en]

Os povos indígenas e o Covid-19 - URL : https://journals.openedition.org/jsa/19804 [pt]

Éditeur

Société des américanistes

Édition imprimée

Date de publication : 30 septembre 2021

Pagination : 323-328

ISSN : 0037-9174

Référence électronique

Paul Codjia et Raphaël Colliaux, «Los Amerindios frente al Covid-19 », Journal de la Société des américanistes [En ligne], 107-1 | 2021, mis en ligne le 30 septembre 2021, consulté le 04 septembre 2022. URL : http://journals.openedition.org/jsa/19799; DOl : https://doi.org/10.4000/jsa.19799

Ce document a été généré automatiquement le 4 septembre 2022.

Tous droits réservés 


\title{
Los Amerindios frente al Covid-19
}

\author{
Estado del arte y revista de prensa
}

Paul Codjia et Raphaël Colliaux

\begin{abstract}
Este texto constituye una breve presentación de una lista de referencias en construcción que reúne obras de diversa índole (textos científicos, artículos de prensa, canales de video, portafolios) que permiten atestiguar sobre las condiciones de vida de los Amerindios durante esta crisis sanitaria mundial. Esta bibliografía, que hemos clasificado en diferentes secciones apropiadas, es accesible desde el sitio web de la Sociedad de los americanistas (www.americanistes.org), que ha inaugurado una columna enteramente dedicada a la cuestión. Si bien los coordinadores de este trabajo, por su particular afinidad con esta región, se concentraron inicialmente en la cuenca amazónica, esta lista de referencias recopilará muy pronto escritos que describen la situación que viven los Amerindios de todo el continente americano.
\end{abstract}


Fig. 1 - A doença do Covid-19, Jaime Diakara'

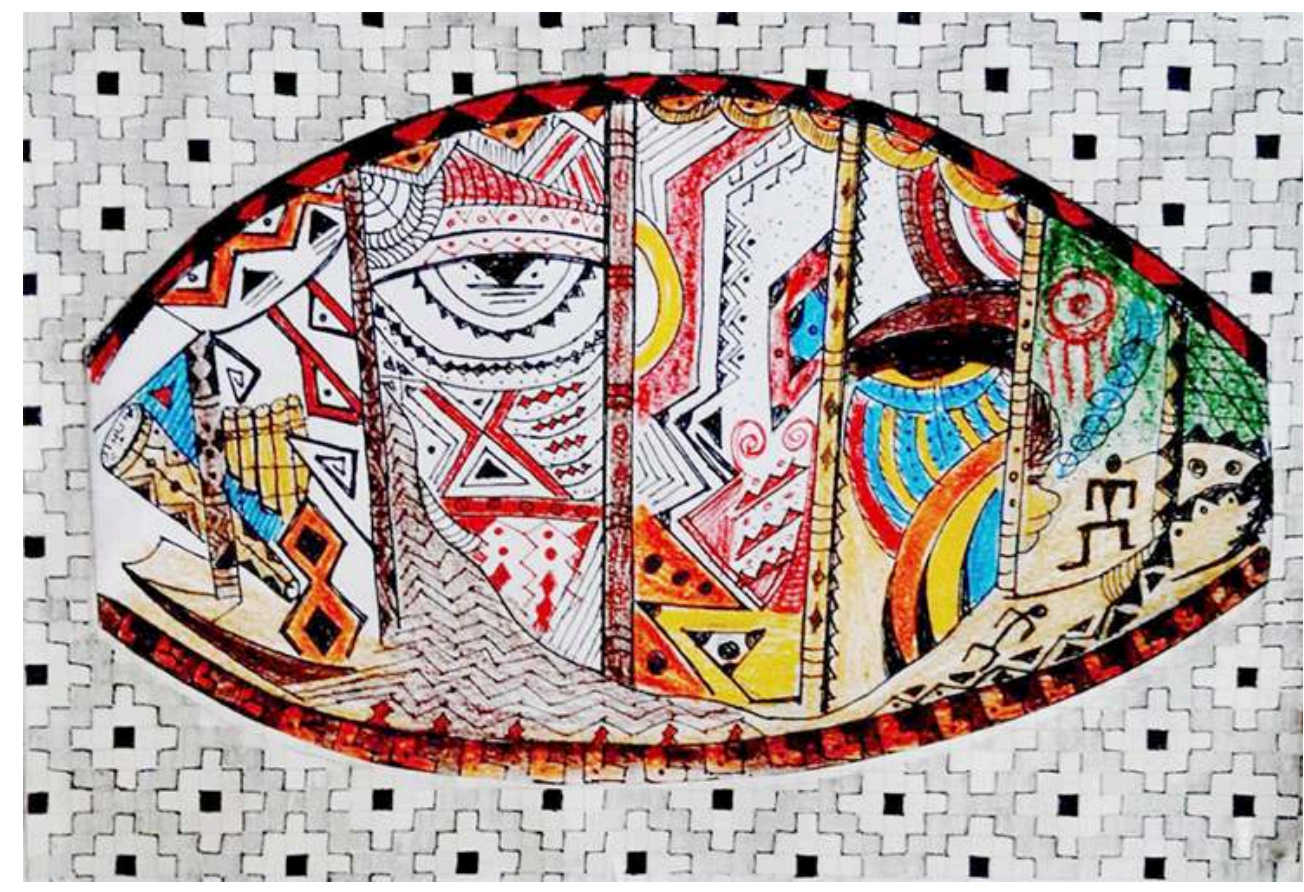

$* * *$

2 Desde abril-mayo de 2020, muchos académicos, periodistas, líderes políticos amerindios o miembros de ONGs han documentado el impacto de la pandemia de Covid-19 en las poblaciones indígenas de la cuenca amazónica. Ya sea en forma de artículos en revistas científicas y blogs, o en periódicos de gran difusión, todos los textos han dado la voz de alarma, cada uno a su manera, sobre las consecuencias sanitarias, sociales, económicas, ecológicas, políticas y antropológicas de la propagación del SARS-CoV-2 en las tierras bajas. Hay que reconocer la capacidad de respuesta y los esfuerzos que ya se han hecho para sensibilizar, pero también para producir análisis y reflexiones en tiempo récord, con el fin de hacer visible la dramática situación en la que se encuentran a menudo estas poblaciones. La pandemia se ha sumado a contextos de precariedad territorial, sistemas de salud deficientes y políticas estatales demasiado desfavorables para los derechos de los Amerindios. El caso de Brasil bajo el régimen bolsonarista es sin duda el ejemplo más trágico.

3 En esta bibliografía no exhaustiva, hemos reunido textos que ofrecen un amplio panorama de la diversidad de situaciones y dificultades a las que se enfrentan las poblaciones amazónicas durante la pandemia. El objetivo de esta recopilación es permitir al lector identificar los problemas, abrir perspectivas de investigación y continuar la labor de documentación, sensibilización y apoyo a los grupos indígenas de las tierras bajas. Obligados a permanecer detrás de las pantallas de sus computadoras para no convertirse en vectores de la enfermedad, un gran número de investigadores amazonistas se ven ahora limitados a intercambios esporádicos con sus contactos y amigos en el campo, y a recoger información dispersa en las redes sociales o los medios de comunicación especializados. La presente bibliografía pretende facilitar estas investigaciones, por lo que una revisión de la literatura científica sobre el Covid-19 en la Amazonia se acerca a un catálogo de prensa, así como de materiales aún no analizados, 
como una colección de enlaces web a instrucciones sanitarias traducidas en lenguas amerindias. Primero, presentamos los artículos científicos y los números especiales de revistas, y después agrupamos los artículos periodísticos en diferentes secciones según el tema que traten.

En este periodo de aislamiento, las propias metodologías de la investigación etnográfica se ven cuestionadas por la pandemia, a fortiori para los investigadores no nativos. Y esta es quizás una importante lección que se desprende de esta revisión bibliográfica aún incompleta: el contexto sanitario parece acelerar la colaboración en los análisis, e incluso en la propia labor de redacción, entre académicos y representantes de los pueblos indígenas. Mejor aún, un número importante de los artículos enumerados están escritos por académicos nativos, especialmente de la Amazonia brasileña. A pesar de las limitaciones, los medios de comunicación permiten un seguimiento y una recopilación de información constante (es el caso, por ejemplo, de páginas de Facebook como https:// www.facebook.com/groups/coronamazon/, administrada por Émilie Stoll y moderada por Ricardo Folhes y Élise Capredon), así como intercambios y reflexiones conjuntas con contactos locales, a menudo, líderes políticos.

5 Sobre el fondo, además de las descripciones frecuentemente cuantificadas de la situación epidemiológica, los artículos aportan reflexiones generales sobre varios ámbitos de trabajo que pueden resumirse de la siguiente manera: en primer lugar, el tema central presente en prácticamente todos los textos es la relación entre los grupos indígenas, los Estados y sus sistemas de salud. Los escritos ponen de relieve la incapacidad de los Estados para satisfacer las necesidades sanitarias de las poblaciones indígenas, debido a políticas sanitarias desiguales, pero también, y quizás más grave, por el desconocimiento de las realidades sociales locales, como las infraestructuras, o las prácticas sanitarias amerindias. Las palabras que los interlocutores indígenas emplean para describir esta situación son muy fuertes. Van desde el campo semántico del abandono en los países andinos hasta el de la ausencia en Brasil, donde los indígenas no se hacen ilusiones sobre las intenciones del régimen de Bolsonaro hacia ellos. A falta de recursos institucionales eficaces para proteger sus cuerpos, los Amerindios eligen proteger sus territorios.

6 Hay, pues, una clara reafirmación de las reivindicaciones de soberanía territorial, una soberanía paradójicamente reforzada por las recomendaciones de los Estados andinos que invitan a los grupos amerindios a cerrar y controlar el acceso a sus tierras. Como lo indica Irène Bellier en varios trabajos, existe un estrecho vínculo entre la salud de las personas y la "salud" de los territorios, un vínculo que es, sobre todo, de carácter nutricional. Regularmente surge la idea de que los alimentos producidos dentro de los territorios indígenas serían una de las condiciones para mantener una buena salud, en contraste con los alimentos provenientes de las ciudades donde el Coronavirus causa estragos en primer lugar. Este deseo de proteger el territorio se manifiesta especialmente en las luchas por frenar las actividades de tala y extracción de oro. En este sentido, y quizás con un toque de ironía, Gregorio Mirabal, el coordinador de la Coordinadora de Organizaciones Indígenas de la Cuenca Amazónica (COICA), afirmaba recientemente: "Tenemos que hacer un proceso de vacunaciones en todos los territorios de la cuenca amazónica con esa vacuna que se llama 'gobernanza territorio indígena' y que es lo único que nos puede salvar."

7 Así, nos llama la atención la mayor legitimidad que han tenido ciertas reivindicaciones territoriales y autonomistas amerindias, debido al vacío dejado por los Estados. Al mismo tiempo, los pueblos indígenas se han enfrentado a una rápida reanudación de las 
actividades extractivas, como la tala, la extracción de hidrocarburos y la minería. En Perú, a partir de mayo de 2020, una serie de decretos eximieron a ciertos sectores económicos de las normas ambientales restrictivas y redujeron los mecanismos de consulta ciudadana sobre proyectos extractivos. La pandemia anuncia potencialmente un doble movimiento: la retirada del poder público, por un lado, y el redespliegue de un sector privado con muchas caras, cuyas actividades son a menudo informales y a veces, incluso, delictivas, por el otro. Los asesinatos de líderes amerindios y ecologistas que se han multiplicado desde el inicio de la pandemia en la Amazonía peruana y colombiana, en particular, son un trágico recordatorio de que los territorios indígenas son más que nunca objeto de codicia.

8 Sin embargo, la aceptación o no aceptación de estas actividades en los territorios amerindios también es objeto de debate entre las propias poblaciones indígenas, sobre todo porque la crisis sanitaria las ha privado a veces de importantes ingresos. Como puede verse, la pandemia agrava viejos problemas, de los que la acción de los misioneros evangélicos protestantes en la región es otro ejemplo. Varias fuentes sugieren que los pastores están aprovechando el miedo generado por el virus para consolidar su influencia $\mathrm{y}$ dar un nuevo impulso a sus ambiciones proselitistas.

9 Si las intenciones misioneras multiplican las preocupaciones, es en particular en relación con los grupos amerindios en situación de "aislamiento voluntario", con los que ciertos sectores religiosos estarían tratando de forzar el contacto, y esto a favor de la profunda reconfiguración de las dinámicas políticas locales, de las que todavía solo percibimos la cara emergente. Desde al menos el siglo xvI, las poblaciones amerindias de la Amazonía han movilizado estrategias de distanciamiento de los peligros inmunológicos (viruela, sarampión, gripe) ligados en particular a la colonización europea, pero quizás también derivados de las zoonosis presentes potencialmente en la selva tropical (véase el artículo de Stephen Rostain ${ }^{2}$ ). En muchos casos, este deseo de aislamiento voluntario se ha visto reforzado a lo largo de los años, a medida que han ido apareciendo e intensificándose nuevas formas de colonización (proselitismo evangélico y católico, agroindustria, explotación de hidrocarburos, minería de oro, tala ilegal, narcotráfico, turismo), ante las cuales las instituciones públicas locales se han mostrado impotentes, e incluso a veces complacientes. Si, debido a su antiguo aislamiento, estos Amerindios siguen siendo extremadamente vulnerables a las enfermedades infecciosas y víricas, el Covid-19 constituye para ellos un peligro considerable que muchos observadores se han esforzado en documentar.

Este tema también sirve de base para una reflexión más amplia sobre la noción de “aislamiento social". De hecho, los acontecimientos actuales tienen el mérito de invertir la percepción de esta práctica como un reflejo primitivo y anacrónico de Amerindios hostiles a la modernidad. Las medidas mundiales adoptadas contra el Covid-19 revelan, por efecto espejo, hasta qué punto estos modos de vida amerindios surgen directamente del contexto social y político -y por lo tanto viral- con el que se han enfrentado estas poblaciones, y justifican su deseo, ahora compartido por los propios Estados, de un aislamiento social proteccionista. En este sentido, la literatura muestra la permanencia, reactivación e incluso legitimación, bajo el efecto de la pandemia, de estrategias de distanciamiento voluntario en esta región del mundo, y más allá.

11 Así, estos textos no se limitan a pintar un sombrío panorama de la situación. También ponen de manifiesto los formidables recursos organizativos, políticos y sanitarios que los Amerindios están movilizando para protegerse, para hacer frente y para tratar de 
detener la dinámica de transmisión del virus. Las iniciativas indígenas están floreciendo para promover el conocimiento y las prácticas médicas locales, y para exigir un verdadero enfoque intercultural en las políticas de salud del Estado.

La epidemia aparece, así, como un "hecho social total" en un contexto poscolonial, un nexo de fricciones incluso entre prácticas de duelo y consideraciones escatológicas divergentes. En este sentido, Bruce Albert nos alerta de la tragedia que viven los Yanomami, que se ven privados de los cuerpos de sus familiares enfermos que han muerto y son incinerados por los servicios sanitarios para evitar el contagio. La bibliografía revela entonces una "situación epidémica" -parafraseando a Georges Balandier-, que reúne más que nunca a todos los actores locales: las poblaciones amerindias diversamente asentadas, los numerosos colonos, las empresas privadas, las instituciones públicas, así como el agente viral. ${ }^{3}$

\title{
Bibliografía disponible en el sitio web de la Sociedad de americanistas
}

http://www.americanistes.org/es/2021/05/30/los-amerindios-frente-al-covid-19/

\section{Resumen de las secciones}

\author{
1. Trabajos de carácter científico \\ 2. Crónicas amerindias \\ 3. Prácticas terapéuticas autóctonas \\ 4. Amerindios urbanos y Coronavirus \\ 5. Las actividades extractivas y la pandemia \\ 6. Los misioneros evangélicos \\ 7. Las poblaciones amerindias en "aislamiento voluntario" \\ 8. Reportajes fotográficos/Portafolios \\ 9. Información institucional \\ 10. Directrices de prevención en lenguas indígenas
}

\section{NOTES}

1. Jaime Diakara es antropólogo y pintor desana (grupo lingüístico tukano, Amazonia brasileña). El autor realizó esta obra tras verse afectado por la enfermedad. Quería expresar así los síntomas que experimentaba. Explica que la parte izquierda representa la infección por el SARS-CoV-2 y cómo el virus tomó posesión de su cuerpo. En la parte derecha aparecen las figuras de su padre y de sus antepasados que, con sus conocimientos ancestrales de las plantas medicinales, le ayudaron a superar el virus. 
2. «Amazonie, une histoire sans geste barrière » [en línea], el 16 de diciembre de 2020 https://covidam.institutdesameriques.fr/amazonie-une-histoire-sans-geste-barriere/, consultado el 25/05/2021.

3. Traducido por Josemaría Becerril Aceves.

\section{AUTEURS}

\section{PAUL CODJIA}

McGill University - Fondation Fyssen - IFEA, miembro del proyecto Amaz (ANR-17-CE41-0013)

RAPHAËL COLLIAUX

IFEA - PUCP - Fondation Fyssen, miembro del proyecto Amaz (ANR-17-CE41-0013) 